\title{
Post-traumatic aortic pseudoaneurysm causing acquired pulmonary artery stenosis
}

\author{
Vinod Singla, ${ }^{1}$ Kunal Mahajan, ${ }^{1}$ Aditya Batra, ${ }^{1}$ Vinay Malik ${ }^{2}$
}

${ }^{1}$ Department of Cardiology, Holy Heart Advanced Cardiac Care and Research Centre, Rohtak, Haryana, India

${ }^{2}$ Post Graduate Institute of Medical Sciences, Health Map Rohtak, Rohtak, Haryana, India

\section{Correspondence to}

Dr Kunal Mahajan,

kunalmahajan442@gmail.com

Accepted 3 July 2018

\section{DESCRIPTION}

A 43-year-old man with a diagnosis of severe pulmonary stenosis was referred to us for pulmonary valve balloon dilatation. We reviewed the case and found that the patient was complaining of progressively increasing dyspnoea over the past one year. He did not complain of chest pain, syncope, limb swelling or cyanosis. History was unremarkable except for a motorbike accident which he suffered 10 years back and sustained injuries over his face, chest and limbs. He made full functional recovery within 2 months after the accident and remained free from any symptoms for the next 9 years.

We reviewed his echocardiogram and found that he had dilated right atrium and right ventricle. Left-sided chambers and valves were normal. The pulmonary valve was normal. Instead, he had supravalvular pulmonary stenosis caused by compression of the pulmonary artery by an extrinsic mass (figures 1 and 2). CT aortic and pulmonary angiography performed on 128-slice scanner

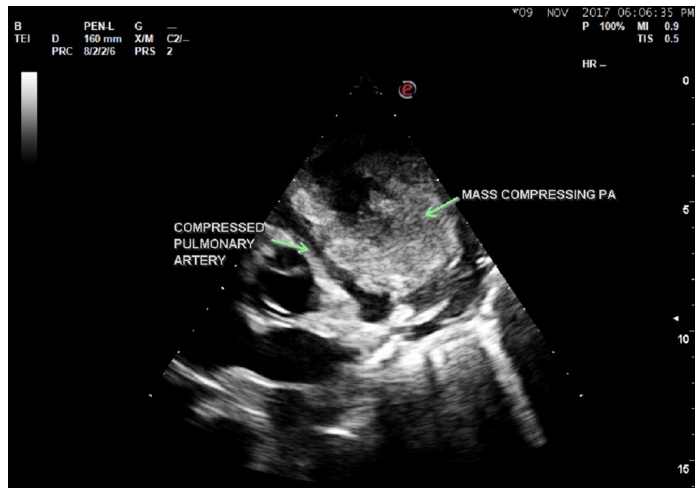

Figure 1 Transthoracic echocardiogram parasternal short-axis view, showing severe compression of the pulmonary artery (PA) by an extrinsic mass.

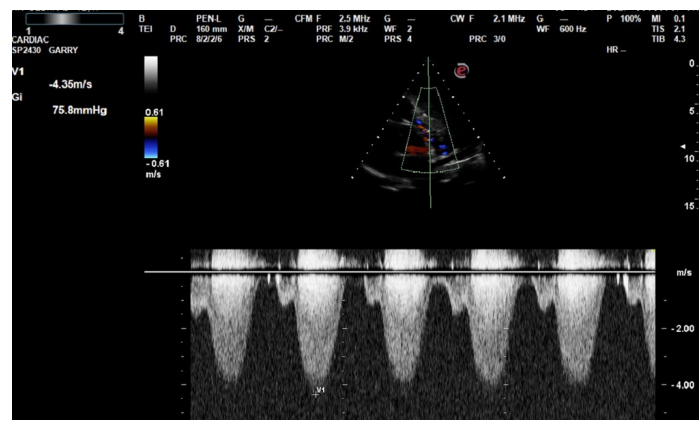

Figure 2 Gradients across the compressed pulmonary artery segment.

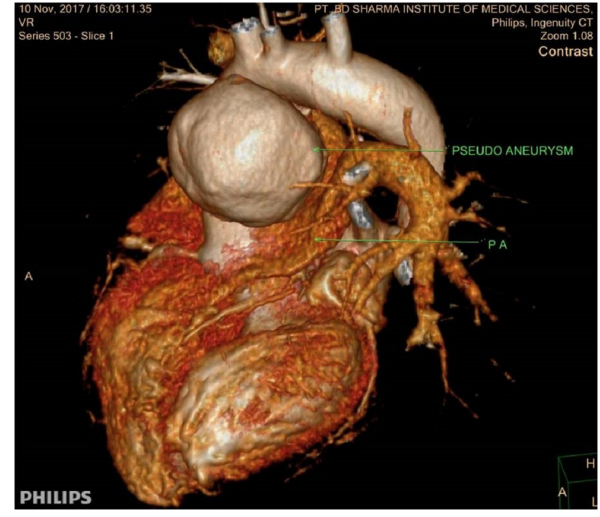

Figure 3 Volume rendered CT image of the heart and aortic arch showing large pseudoaneurysm from ascending aorta compressing the pulmonary artery (PA).

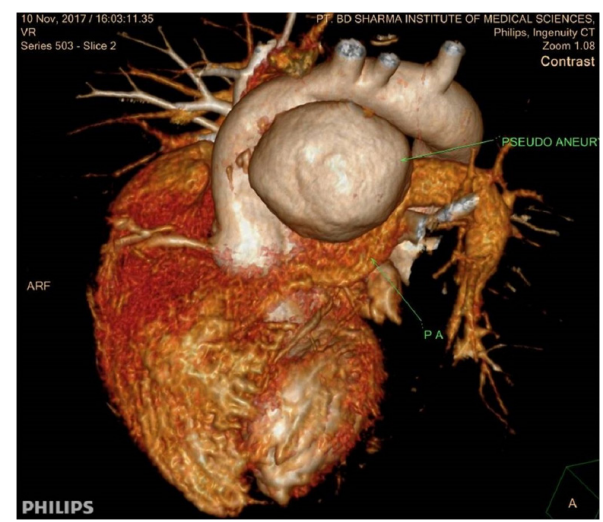

Figure 4 Pseudoaneurysm severely compressing the main pulmonary artery (PA).

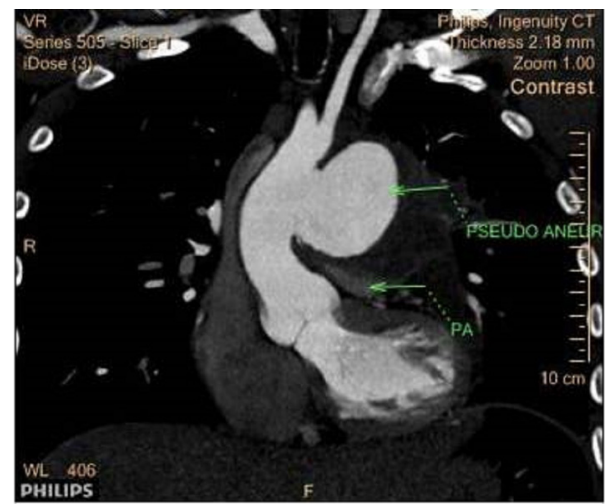

Figure 5 Coronal CT angiography image showing large peripherally thrombosed aneurysm of ascending aorta compressing the pulmonary artery (PA) with resultant severe compression and decreased contrast enhancement of pulmonary artery. 


\section{Learning points}

- Most of the cases of traumatic aortic transections are fatal.

- Approximately $2 \%$ survive long enough to develop chronic pseudoaneurysm.

- The most common site of post-traumatic pseudoaneurysm is aortic isthmus (between the left subclavian and the third intercostal artery).

- However, other aortic sites including ascending aorta have also been reported.

- If left untreated, chronic pseudoaneurysm typically expands progressively and causes compression of surrounding structures (may lead to dysphagia, hoarseness, etc).

- Compression of the pulmonary artery by chronic posttraumatic aortic pseudoaneurysm is rarely reported.

- Differential diagnosis includes infected mycotic saccular aneurysm, penetrating atherosclerotic ulcers and vasculitis.

revealed large peripherally thrombosed pseudoaneurysm of the ascending aorta, which was compressing the pulmonary artery resulting in marked narrowing and decreased contrast enhancement of the pulmonary artery (figures 3-5). Rest of the aorta was free of any signs of inflammation, atheromatous plaquing and dilatation, ruling out vasculitis, infected aneurysms and atherosclerosis as the aetiology of the pseudoaneurysm. Detailed work-up for connective tissue disorders, infective pathologies, vasculitis and hypertension was negative. The pseudoaneurysm was therefore assumed to be post-traumatic in origin. The latter usually involves the aortic isthmus; however, other aortic sites including ascending aorta have also been reported. ${ }^{1}$ The patient was advised surgical repair, for which he declined and was lost to follow-up.

Contributors VS, AB and VM made the diagnosis and performed the complete investigations and were involved in the management of the patient. KM wrote the manuscript. All authors read and approved the final version of the manuscript.

Funding The authors have not declared a specific grant for this research from any funding agency in the public, commercial or not-for-profit sectors.

Competing interests None declared.

Patient consent Obtained.

Provenance and peer review Not commissioned; externally peer reviewed.

\section{REFERENCE}

1 Zamani J, Aghasadeghi K, Zarrabi K, et al. Pulmonary artery stenosis caused by a large aortic arch pseudoaneurysm detected 10 years after a minor trauma.J Cardiovasc Thorac Res 2016;8:46-8.

Copyright 2018 BMJ Publishing Group. All rights reserved. For permission to reuse any of this content visit

http://group.bmj.com/group/rights-licensing/permissions.

BMJ Case Report Fellows may re-use this article for personal use and teaching without any further permission.

Become a Fellow of BMJ Case Reports today and you can:

- Submit as many cases as you like

- Enjoy fast sympathetic peer review and rapid publication of accepted articles

- Access all the published articles

- Re-use any of the published material for personal use and teaching without further permission

For information on Institutional Fellowships contact consortiasales@bmjgroup.com

Visit casereports.bmj.com for more articles like this and to become a Fellow 